\title{
Village Democracy: The Deliberations of Voting
}

\author{
Zaini Ali \\ Lecturer at Islamic University of Riau \\ Pekanbaru, Indonesia \\ Zainiali2014@gmail.com
}

\begin{abstract}
The lowest governmental units as at once the spearhead of community service, the village was Soko guru first and foremost the birth of democracy in Indonesia. The position of the village as a community can be viewed from two angles, that is, as a gathering place for the community to resolve the issue in its own way of life, then the village as a bureaucratic machine in serving the interests of the Government in it. First, the point of view of the village as a community institution solving consensus based on the principles of, by and for themselves through deliberation. This deal was born of political institution through a Village on the island of Java, called the "village of Rembug", while in Sumatra, such as in West Sumatra is called "the rope Tigo Sapilin" (the fusion of three elements, namely; Governments, scholars and leaders of Customs), as a parliamentary institution in the village that the implementation is done by the Government of the village. The dynamic state of the village like this goes up with each passing regime the old order to the new order regime. In West Sumatra, agreement pattern of the three leaders of the Villages (Nagari) has many national leaders, you name it, Imam Bonjol, Agus Salim, Tan Malaka, Sutan Syahrir Muhammad Hatta, Mohammad Nasir, Hamka and others. The second point of view, see the village as a bureaucratic machinery which enabled serves the interests of the Government on it, and it will last until the inception of LAW number 6 Year 2014 of the village. Pattern making in the village in the deliberation room or give the most votes. The fact showed almost all legal products in the village is done with the most votes (voice vote). Even APBDes like village rule approval is so urgent and strategic for the people's interests above discussed enough approved by Chairman of the BPD involves without BPD as the political institutions of the Parliament or the village. The loss of the principles of deliberation in the setting of policy in the village other than the Government does not want to know the character of the different Villages in Indonesia, as well as the village of an organism which can be seen as a set of policy and receive all of the above. No one resisted the Government policy openly, but secretly and massive there is resistance from the people of the village. Due to the application of the policy of the
\end{abstract}

village as the bureaucracy serving the Government on it, the village can no longer prepare the prospective leader of the local level, regional national-populist let alone unless leaders, including leaders in the village, have to deal with law enforcement.

Keywords: Democracy, Deliberation, and Voting

\section{INTRODUCTION}

The existence of the village as a unit of Government that most low in Indonesia has been known long before the Republic was born. Even Sadu1) says that villages in Indonesia for the first time, found by Mr. Herman Warner Muntinghe, a member of the Raad van Indie on English colonial occupation, which is a United Kingdom Governor General helpers Mastering Nusantara years 1811. In a report dated July 14, 1817, to his Government, Mr. Herman Warner Muntinghe explained that there are villages in the area along the North Coast of Java Island.

The lives of the people of the village of archipelago region when it depicted Tonnies in Surianingrat2), as the community gemeinschaft or community where human relationships are personal, intimate, familiar with the familiar bitter as nicely as, seduka-way and accompanied by mutual trust. Tonnies said relationship is rooted in the unity of the derivative, the unity of the family. The community has the unity of indigenous, and confidence, even ownership or besifat work also reflects, all sesutu performed together, in mutual. To farm, build a House, make roads and bridges and others with mutual.

After the United Kingdom leaving the Malay Archipelago and further according to Surianingrat3), came also a Netherlands colonial State, and issuing policies about the village, with a distinguished law on villages that existed on the island of Java and The island, with villages that exist outside of Java and Madura. For villages that existed on the island of Java and Madura Netherlands Indies Government year 1906 the village set up through the Elementary Ordonantie Municipality (IGO). While the Netherlands Indies Government 1936 year issued policies for villages outside Java and Mandura through Inlandsche Municipality Ordonantie Buitengewesten (IGOB)4). According to 
Soehino5), issued the ACT about the village both IGO or IGOB by the Government of Netherlands more recognition of position and authority of the Village setting. This is in line with what is said to be Surianingrat. 6), that the village is left has the authority to take care of the household according to his will in the police force as well as the settings but in its villages are not fully free. The village was given the autonomy with regard for the regulations made by the Governor-General, the heads of Government of the Union of the region or community that stands on its own, designated by Ordinance. The recognition of the Government of Netherlands Hinda against villages in the archipelago, according to Suhino6), can be seen from the village government issues went under the head of the village. The goal of the Government of the Netherlands East Indies to put forward the recognition rather than setting due to without costs or energy they gained a greater advantage in addition to not invite people's be moved can also conflict in accordance with interests of the Government of the Netherlands East Indies.

Then after Indonesia became independent of the position of the village set in law number 22 Year 1948. During this time even until now the Village autonomy enacted according to Sadu7), is the recognition of autonomy and not granting autonomy. But in law number 22 Years the 1948 Foundation of the autonomous status of the village (the granting of autonomy) level 3, as autonomy apply to the provinces as a region of level I, and district/city as level 2 . Next on the ACT which replaced the ACT number 22 Years 1948 , i.e. the number 1 of the year 1957, the village also has been established as the autonomous region level 3 as well as in law number 22 Year 1948. But the spirit of a political desire to make the village as the autonomous region level III has not been manifested. Although the desire to make the villages as the autonomous region level 3 has not yet materialized, the villages existing autonomous Villages still run as usual. The Government of the village according to Surianingrat8), as the lowest governmental units organized by 3 elements, i.e. the village head, Village and meeting teachers ' village.

One of the elements of the Government of the village in question is Meeting the village as part of the enforcement of the village Democracy. According to Hatta9), democracy village on the mark with this:

a. Meetings (deliberation and people's place to agree),

b. People's right to hold a protest, and ideal please help,

c. The traditional political structure which is feudal and autocratic.

In the language of the people of the interested village, they wear the term meeting of the village Board term compared to the village or the Village Representatives. The reason they did Surianingrat10) is to avoid the mistakes the sense because of the only similar Meeting a representative of the people. Meetings of the village Government consists of only the village coupled with those reserves the right to select the head of the village and the people who are seen according to the custom fitting takes part in village meetings, such as religious teachers, employees of the mosque includes custom figures. In addition to the various elements involved in building democracy village, village chief is also inseparable from the consent of the meeting of the village. Next Surianingrat11) a number of actions the village chief who is bound by the decision of the meeting of the village, among them;

a. In holding a borrowing money over a dependent village.

b. In the Treaty which damning, for example, to obtain land, releasing land, pledge land, pledge village buildings and goods move more.

c. In holding a first degree in law as well as the level of appeal or Cassation, demanding or accepting the decision.

From the excerpt above, look how the village as a community from many different groups or groups build a system that regular life through deliberation and agreement in order to avoid things that will burden the people. Parties given power (Government) will undergo all agreements previously decided by the groups gave the mandate (i.e. governed (the people) in order to mutually beneficial cooperation that built towards the autonomy of the village a dynamic.

The fact of running agreement and deliberation within the Government so that the people's rights to protection from harmful things himself as an owner of sovereignty in the Country can be avoided. In connection with the land in the practice of the Organization of Government, the principles of deliberation are always ignored although the essence of democracy itself is pillars human values. When the consultative and agreement ignored apart from truth is not in favour of the truth but will favor the justification, then the village of democracy here in the search process identity, whether to stick with values based on wisdom local or adjust yourself with the pattern of modern democracy, namely the most votes determine the truth or justification?

From a number of the questions above, then the main two questions formulated in this paper namely, how the application of the village of democracy during the new order regime, and how the application of democracy village after the new order regime toppled (reform era)?

\section{DISCUSSION}

\section{A. Democracy Village on the new order era}

Days of the new order regime after the fall wake up old order Government with the local governance system legislation alternates became a point of national political proe. For example the inception of LAW number 22 Years 1948, not how long was replaced by LAW number 1 Year 
1957. Furthermore the ACT number 11957 Tahin was replaced again by the determination of President Number 6 years 1959 about the consummation of LAW number 1 Year 1957. Then not how long this run, ACT out anyway ACT number 18 Year 1965 that set of local governance. In any ACT unless the ACT Number 18 1965, the village position set that was once even autonomy recognized and through local governance ACT thus Village was made an autonomous region with the principle of autonomy is given as provincial and district area and the city. But until the birth of ACT Number 181965 the policy to make the village be given autonomy cannot be realized. Or with others, the desire to make Village as a three-level autonomous region cannot be realized. The intention to make the village became an autonomous Region level three is regulated and licensed by the Government through its own ACT, namely ACT number 19 of the year 1965 about the villages of the Township. But it is a pity the fate of ACT number 18 Years 1965 about local governance and ACT number 19 of the year 1965 on Village quite yet implemented because the regime of power changed from the old Order to the new order.

In the new order era, the fate of Village democracy is increasingly at stake after the ACT about the village issued through ACT No. 5 of the year 1979. Philosophical in personal religious beliefs in this ACT is "Diversity in unity". As a result existing villages outside Java are also his character is thus uniformed starting from the name, form, composition, as well as the position of the Government of the village of 12). While the existing villages outside Java are as varied in accordance with the character of the people. The condition of the village beyond the Java lost his true identity is revealed by a Liddle quoted Johan in Haris13) says uniformity based on policy conceptions of Javanese people made so only by Jakarta, such as ACT No. 5 of the year 1979 on The village government, which led to the breakdown of community values and ethnic social institution outside of Java (for example, his country, the amount and the Minangkabau people of South Sumatra). The award is given by the Government against the rites, but not in the political and social economy.

The village of uniform policy at first is to simplify the construction but the villages outside Java thus feel unfamiliar with the patterns used include Village Governance institutions in the conduct of it. According to Zakaria in Gunawan14) the village not only changed its status, i.e. from "law society" into a group of people living together, but also in it fitted a new institution, namely the Government of the village. The loss of local wisdom values in various Villages outside Java also raises suspense Widjaja14 which says "the Act number 5 Year 1979 concerning the governance of the Village turned out to weaken or eliminate many elements democracy for the sake of uniformity form and arrangement of the Government of the village. Next Widjaja said the village democracy is no more a mere dream and still is the slogan in the rhetoric for solace. The villagers can't empower himself and even the longer the increasingly weak and helpless.

\section{B. Democracy in post-war new order}

ACT number 22 Year 1999. The birth of ACT number 22 Year 1999 about local governance is a major pillar in the development of democratic Governance at both the central level, as well as the area of the village. The village is almost a quarter of a century ago suspended. The thought Foundation of the rule of LAW in the Village can be seen in overview in the setting of the village government is about diversity, participation, autonomy, democratization and community empowerment 1 . As defined in the Overview (9), grains of 1.

a) In law number 22 year 1999

This position Parliament Village, Village Representative body (BPD) visible strengthened because of the village chief's responsibility on BPD. As the agency representative, BPD has the function of the trial, legislating, supervise and accommodate the aspirations of the community. According to Jaka15) as for the elucidation of the functions of the BPD are:

a. Trial Functions delegated in BPD to keep sustainability customs alive and thriving in the village all support the continuity of development.

b. The function of the legislation is to formulate and define the rules of the village alongside the Government's village,

c. Supervisory Functions include the implementation of the regulation of the village, the budget and revenue villages.

d. The function of accommodating the aspirations of the community, namely addressing the aspirations of the community to officials or authorized instance.

Of the functions of the BPD above seen a number of authorities which owned BPD as Parliament village. However, by using a system of representatives thus this does not correspond to the values that exist in the community. According to the view of the Barber in Jaka16), that tends to be liberal representative shittim does provide a solid foundation for freedom and equality of citizens in the democratic community level. Adherents of the communitarian are convinced that people always in a community rather than an individual bond because representative democracy tends to create an Alliance of public participation and is not able to meet the needs of the public. Next Walzer in Jaka17 saying that communitarians are indeed paying attention towards the autonomy of individuals as the House of liberal democracy, but freedom is not popularized, but individual autonomy as well as 
awards at the chance to actualize itself in the collective bond.

\section{a) LAW Number 32 Year 2004}

On the ACT Number 32 Year 2004, the Government of the village set in article 200, and in article 200 (1) said "the Government of the village consists of the Government's consultative body of the village and the village. Description of the article and the text is clear that one of the elements of the organizers Government of the village is the representative body of the village. Hereinafter in article 209 of the Agency's Consultative function of the village, which is set Regulations of the village together with the village chief and channeling the aspirations of the community. When compared with law number 22 Year 1999, some functions of the BPD under Law Number 32 Year 2004 to shift the task of the BPD. For example, one function that slides and on the move task BPD is a function of scrutiny against organizing village rule or regulation the village chief. According to PP Number 72 of the year 2005, on the implementation of article 200 of the village said that in carrying out its functions, BPB in gives a number of authorities, namely:

1. Discuss the draft regulations of the village along the village head,

2. Carry out surveillance against the implementation of the rules and regulations of the Village Head, Village

3. Propose the appointment and dismissal of the head of the village,

4. Forming the Election Committee head village,

5. Dig, accommodate, gather, formulate, and channeling the aspirations of the community, and

6. Drawing up the code of conduct BPD.

Of a number of authorities which owned BPD as describe above, from the various studies, such as Ion Bastion18) who is doing research about the authority of BPD in the village of Koto Curry, one of the villages in the Sub-District of Central District of Kuantan Sengingi, then He19) that conduct research in the village of Sukamaju, district Ukui, Pelalawan Regency, as well as S20) performs research in the village of Sungai Batang, Batang River subdistrict, district of Indragiri Hilir, find a number of the real facts that from 6 authority given to the BPD only one authority is exercised by the BPD in the third study, namely the Village authorities in discussing the draft regulations of the village along the village chief. From the discussion of the draft Regulations of the village, which is routinely done is design drafting APBDes. Even in the third study, BPD Village never discusses in institutional, but Chairman BPD on behalf of BPD agreed the proposed APBDes draft proposal of the head of the village. And a portrait of the behavior of BPD in using the authority of the Parliament of villages in three villages of research describes not its weight
BPD as people's consultative agency or agreement don't go as the mandate of the ACT. In other words the BPD in villages in the Regency of Riau Province not running his political authority, as appropriate.

\section{b) LAW number 6 Year 2014.}

On the LAW number 6 Year 2014 about a village, a seat of the BPD as Parliament Village set in article 55. Further, in section 55 is said to have BPD function:

a. Discuss and agree on the draft regulation of the Dsa along the village head;

b. Accommodating and channeling the aspirations of the community of the village;

c. Monitor the performance of the village chief.

Unlike the BPD which is set in Law Number 32 Year 2004, where a number of authorities in the BPD give in detail in carrying out its functions, while BPD in law number 6 Year 2016 thus the authority to run a function that BPD is removed. Seen from the aspect of governance, removal of the management authorities of the BPD in execute functions means limiting the functions of the BPD are running its role as Parliament's Village in fighting for the rights of its people as owners of power.

Concerning the application of the ACT the village legally already issued, but there is no defacto district/city that sets the position, order, function and structure of organization Village Government as the mandate of the ACT has not yet been realized. Thus until recently, when the PP remain works BPD Number 72 Year 2005 about the village as a translation of Article 200 of the ACT Number 32 Year 2004 about the Government area.

\section{CONCLUSION}

As the embodiment of the State independent of the people, the seat of the agency of the people in the Government, began a national level, the regional level or the level of the village is a must. Because it is through the power of the State, the Government has issued numerous policy especially the position of the Parliament in the village with a variety of designations, such as the institution of the Village Council (Law No. 5 of the year 1979), then the village representative body (law number 22 Year 1999), then the Agency's consultative Village (Law Number 32 Year 2004) as well as to the name of the village parliament the latter remain in the call with the other name of the village or agency (law number 6 Year 20014).

Regardless of any Parliament in the village name set of each Act, the necessary is how Parliament Village as the village people's representation can be made through the given functions. But from the fact that there were real turns 
out these functions cannot be run BPD, as appropriate. Although BPD as institutions become partners of the Government of the village organized a Government, particularly in Riau Province, it seems that only featured as the BPD as complementary and not as protectors of the governance and administration and fighting for political rights the people in the village. And very reasonable when there is a phrase that says the construction of the village more mobile because mobilized and not because participation as belonging to the people. This condition has been running since the new order regime until now.

\section{REFERENCE}

[1] Gunawan, Iman, Metode Penelitiaan Kualitatif: Teori dan Pratilik. Jakarta: Bumi Aksara, 2013.

[2] Bayu Surianingrat, Pemerintahan Administrasi Desa dan Kelurahan, Aksara Baru, Jakarta, 1985.

[3] Soehino, Hukum tata Negara Hukum Perundang-Undangan (perkembangan pengaturan mengenai tata cara pembentukan perundang-undnagan, baik tingkat pusat maupun daerah), BPFE, 2007.

[4] Sukardi, Metodologi Penelitian Pendidikan, Yogyakarta, Bumi Aksara, 2007.

[5] Sadu, Prospek Pengembangan Desa, Fokus Media, 2007.

[6] A.W. Widjaja, Administraasi Kepegawaian. Rajawali, Bandung, 2006,

[7] Undang-Undang Nomor 6 Tahun 2014 tentang Desa

[8] Undang-Undang Nomor 32 Tahun 2004 tentang Pemerintahan Daerah

[9] Peraturan Pemerintahan Nomor 72 Tahun 2005 tentang Desa

[10] Undang-Undang Nomor 22 Tahun 1999 tentang Pemerintahan Daerah

[11] Undang-Undang Nomor 5 Tahun 1979 tentang Pemerintahan Desa

[12] Undang-Undang Nomor 18 Tahun 1965 tentang Desa Praja

[13] Undang-Undang Nomor 1 Tahun 1957 tentang Pokok-Pokok Pemerintahan Daerah

[14] Undang-Undang Nomor 22 Tahun 1948 tentang Penetapan Aturan-Aturan Pokok Mengenai Pemerintahan Di DaerahDaerah Yang Berhak Mengatur dan Mengurus Rumah Tangganya Sendiri 